\title{
Autonomy and participatory aging: a dialogical practice
}

\author{
Giselle Massi ${ }^{1}$ \\ https://orcid.org/0000-0003-4912-9633 \\ Maria Cristina Miller Chaves ${ }^{1}$ \\ https://orcid.org/0000-0001-8359-6679 \\ Frances Tockus Wosiacki ${ }^{1}$ \\ https://orcid.org/0000-0002-5940-139X \\ Adriele Paisca ${ }^{1}$ \\ https://orcid.org/0000-0003-1966-7705 \\ Roxele Ribeiro Lima1-2 \\ https://orcid.org/0000-0002-9914-4789 \\ Rita Tonocchi ${ }^{1}$ \\ https://orcid.org/0000-0001-7006-0541 \\ Ana Paula Hey ${ }^{1}$ \\ https://orcid.org/0000-0003-2495-3474
}

Universidade Tuiuti do Paraná, Curitiba, Paraná, Brasil.

${ }^{2}$ Associação Educacional Luterana Bom Jesus - IELUSC, Joinville, Santa Catarina, Brasil.

Research support source: The current study was held with the support of the Coordination for the Improvement of Higher Education Personnel (Coordenação de Aperfeiçoamento de Pessoal de Nível Superior - Brazil (CAPES) - Funding Code: 001.

Conflict of interests: Nonexistent

\section{(c) (i)}

Received on: September 10, 2019

Accepted on: October 7, 2019

Corresponding address:

Giselle Massi

Rua Benjamin Lins, 750, apto. 61

CEP: 80.420-100 Curitiba, Paraná, Brasil

E-mail: giselle.massi@utp.br

\section{ABSTRACT}

Purpose: to understand the effects that dialogical practices can have on the social participation and autonomy of people over 60 years old, as well as the way they face their own aging.

Methods: this qualitative study was based on the dialogical discourse analysis, which considers language as the practice that organizes and signifies human actions. Thus, after dialogical practices developed during weekly meetings of 90 minutes, focused on oral, reading and writing activities related to elderly people's life stories, the aged participants responded to a semi-structured interview.

Results: the results allowed verifying that dialogical activities had positive effects on elderly people's social participation and autonomy, so, they could have: a) more confidence and freedom to use the language; b) strength and reassurance to make decisions; c) more possibility to cope with aging; d) enhancement of their self-esteem and self-worth.

Conclusion: it can be concluded that activities based on dialogical practices can promote an active, participatory aging, with a better quality of life.

Keywords: Aging; Social Participation; Personal Autonomy; Language 


\section{INTRODUCTION}

Aging is a unique and progressive process throughout the existence of every living being. In humans, this process does not meet the mere natural relation between biology and biography. Contradicting such reductionist position, studies point that the existence of each human being, apart from the organic aspects, depends on cultural, socio-economic, educational and occupational aspects, among others, which are interdependent and related to each individual's singular story ${ }^{1}$.

Although it is not possible to define a certain age to define an individual as elderly, in the legal point of view, the World Health Organization ${ }^{2}$ considers that old age starts at 65 years old, in economically stable countries, and at 60 years old in poorer, more socially vulnerable countries. Under such chronological foundation, the bottom of the age pyramid, entailing children and young individuals, is narrowing, while its top, comprising individuals over 60 years of age, is widening, peaking with the world demographic aging ${ }^{3}$.

In this context, Latin America has undergone deep change, featuring the fast-paced aging process of its population, as well as socio-economic and educational inequalities, strongly reflected on old age. Such inequalities usually report social disadvantages, accumulated in a lifetime, and reflect on the elderly's health status and autonomy. The awareness of these disadvantages has contributed to the development of legislations that share the will to mainstream the specific needs of that age range, including it in the set of public policies and intersectoral legislations ${ }^{4}$.

In Brazil, the Elderly National Policy ensures social rights to individuals of over 60 years old, pointing to the need of creating conditions to promote their autonomy, integration and effective participation in society. Therefore, the proposal is to face one of the greatest challenges in current Brazil, once it is concerned with keeping the elders active in a society where aging is associated with disability and inertia ${ }^{5}$. In addition, the National Health Policy to the Elderly (Política Nacional de Saúde da Pessoa Idosa-PNSPI) aimed to recover, keep and promote elders' autonomy and independence, pointing out the community engagement of these subjects as one of the foundations able to reduce age-related preconceptions ${ }^{6}$.

In this sense, those public policies foster the creation of a favorable social environment to active aging, aiming at the promotion of elders' quality of life, by means of the universal access to public health services and the consideration of social determinants. They point out a broader concept of health which, apart from the presence or absence of diseases, has to do with autonomy and independence, that is, the ability for older people to make decisions, value their identities, and their right to come and go freely, and the possibility to build better personal and collective life conditions ${ }^{7}$.

In the scope of the Health Promotion, language practices play a fundamental role in the process of active aging, to the extent that language, as an interactional activity ensures elders' ongoing participation in the community that they live in8. Language is an inter-subjective activity, which organizes and gives meaning to human actions, enabling reflections, re-meanings, decision making and, concomitantly, promoting changes in the way that individuals relate to themselves or to the others around them9.

Thus, if in the light of attention and care, Health Promotion is defined as a strategy of health production, developed by means of listening and reception of stories and life conditions, then, language is a fundamental activity. In addition, according to Bakhtin ${ }^{9}$, language, while a dialogical activity, is related to life, within utterances that unveil and organize life contents in all the cycles of the human existence. It is by means of the language, understood in its dialogical view, that any human interactions, including that established between researcher and researched-subject, may generate other possibilities to both of them, making words go around and promoting the authorship to what is said and lived ${ }^{8}$.

Hence, this study aimed at understanding the effects that dialogical practices can have on the social participation and autonomy of people over 60 years old, as well as the way they face their own aging.

\section{METHODS}

The current study was associated with a program of university extension, and was approved by the Research Ethics Board (102/208) of the Universidade Tuiuti do Paraná, Brazil. Therefore, meeting that Board criteria, all participants signed the Free Informed Consent Form, being informed that their participation was free, and they could quit the study at any moment, without any harm or justifications.

It is a qualitative research, founded in a dialogical perspective of the discourse, according to Mikhail Bakhtin', which considers that meanings are collectively built, exploring the unique profile of the subjects within a certain community. 
In the dialogical perspective, a qualitative study assumes that its participants are constituted in their social relationships; therefore, their discursive productions only make sense due to the ties established with the others' discourses ${ }^{10}$. Thus, going beyond positions of neutrality ${ }^{11}$, investigators and participants interact, re-elaborating their positions and ways to conceive themselves and the circumstances that are part of their story. Once enunciations are not neutral, but produce meaning effects on the dialogue speakers, dialogical qualitative analysis sets apart from viewing the participants as mere informants, whose discursive productions are only transparent utterances, disregarding the enunciative contextin which they were elaborated. On the contrary, the dialogical analysis of the enunciations considers the concrete situation where discourses were produced, keeping in mind their broader social nature ${ }^{12}$.

In that sense, it should be observed that the participants in the current study are elders from a program of university extension, named Language Workshop, aiming at the health promotion of people over 60 years old. That workshop entails an activity of language promotion, by means of dialogical practices related to utterance, reading and writing. It is organized in the form of meetings where the elderly discuss themes of their own interest: childhood plays, formal and informal activities that they carried out along their lives, songs and photographic images that marked their life story and memories, among others. The meetings were ninety minutes long each, and they were held at the same university every Wednesday, along with students and researchers involved with the aging and old age themes.

Specifically, during 2016, the elderly from the Workshop participated in several interactional activities, read several texts on themes related to quality of life and active aging. During the first semester, reading those texts triggered dialogues among the elderly, the students and researchers. In this dialogical process, all the involved individuals interacted orally about conflicting positions, questioned and re-signified crystalized meanings on aging, health, autonomy and social participation of people aged over 60 years.

In the second semester of 2016, after the reading practices, the elderly produced texts, structured on their reported personal experiences, around aging and their future projects. Each participant would read excerpts of their stories, and the others would listen and make comments about. Subsequently, each one of them wrote his(her) account and read to the others, who would ask questions, point gaps, gave suggestions, thus, raising questions on formal and discursive aspects of the elaborated texts.

Participants' questions underpinned the personal re-elaboration of the text productions. Finally, after that activity of writing and rewriting, the text of each elderly participant was changed into a book chapter. Thus, with the dialogical perspective as background for that task, once language as symbolic activity promotes the continuous reorganization of each person's story, the participants allowed themselves to write their own personal accounts, publishing, in the social networks, an e-book called "Let the elderly speak".

After the end of the activities in November 2016, the elderly were invited to respond, orally and individually, a semi-structured interview. Besides questions related to their socio-age profile, the interview comprised questions which aimed to understand the role that oral activities, based on a dialogical perspective of the language, may play in the promotion of autonomy and coping with old age in the process of active aging. Regarding the inclusion criteriain this research, it was necessary to be over 60 years of age and take part in the Language Workshop throughout 2016, no matter the reported complaints or comorbidities.

Interviews were recorded in a Lenovo K5 equipment and further transcribed and analyzed. The unit of analysis in the study was the dialogical activity itself, developed during the interview, which corresponds to an interactional, semiotically mediated activity, according to the dialogical perspective that underpins this study. This interview, understood as a discourse genre, was assumed as a concrete enunciation, within a discursive chain, generating responses, that is, responsive attitudes in the dialogue participants: elderly subjects and researchers. Therefore, the guiding questions, which organized participants' own dialogue, are configured in the clarification of the axes presented in the results. Such questions precede the responses elaborated by the elderly, being possible to consider the discursive context where the accounts were produced, as subsequently elucidated.

\section{RESULTS}

First of all, the current research had seven participants, six females and one male, recognized by the following aliases: Aphrodite, Artemis, Zeus, Hestia, Hera, Demeter and Athena. They are identified with the names of Olympian gods and goddesses, in an allusion 
to the Greek thinking and civilization's influence on the Western world, similar to the elderly's influence on the new generations.

The study results are organized in 3 parts. The first one features participants' socio-educational profile. Subsequently, the second and third parts represent, according to the dialogical perspective of the language, two axes of analyses with aspects related to the autonomy and coping with aging, respectively, keeping in mind the role that utterances may play in the health promotion during the aging process.

\section{Profile of the research participants}

Regarding participants' sociodemographic profile, factors related to their age, gender, marital status, income and schooling are presented below:

- Hera isa retired, 85-year-old widow. She gets two minimum salaries a month. She lives alone, interacts with her neighbors and groups that she joins. She graduated from Higher Education.

- Hestia is a retired, married, 62-year old woman, who lives with her husband and son, and gets one minimum salary. She interacts with her grandchildren and brothers. She concluded high school.

- Aphrodite is a retired, 66-year-old divorced woman who lives alone. She interacts with her mother, brothers, children, grandchildren, other family members and friends. She is a higher education graduate.

- Demeter is a retired, 65-year-old widow, who lives with her son. She did not conclude middle school (9 years).

- Athenais a single, retired, 85-year-old woman that gets one minimum salary. She lives with one of her daughters and two granddaughters, and interacts with her neighbors and friends. Athena never attended school.

- Artemisis a married, retired, 67-year-old woman. She lives with her husband, interacts with her son, neighbors and other family members. She has incomplete high school.

- Zeus is a married, retired, 66-year-old man who gets two minimum salaries. He lives with his wife and daughter. He attended until the second grade of elementary school.

\section{First axis: the influence of the Language Workshop on the autonomy and decision- making}

This axis points out the role that dialogical activities may play, specifically on the promotion of autonomy during the old age. In order to understand whether the Language Workshop has influenced on the participants' autonomy and decision-making, the following questions were elaborated: 1) "Do you understand that your participation in the Language Workshop has influenced your autonomy? Yes? No? Why?"; 2) "Has your participation in the Language Workshop influenced your decision-making? If so, which decisions?".

Subsequently, the responses on the autonomy and decision-making given by the participants in the Language Workshop.

Hera: [...]Yes! For example, in writing, sometimes I was afraid of writing something, and the Workshop gave me a certain freedom, it released me from some preconceptions or things like that.

Hestia: It influenced me because I think I had autonomy, but today I'm more confident to make decisions, I learned more...it strengthened my will, my potential, which was somewhat kept inside me, evolved... it is easier for me to express things, my will. Many things I didn't use to do, now I do.[....].

Aphrodite: Because we realize that we can. Because I think I'm getting old, but I'm getting better. I don't say no to anything, even if I don't know, I search for getting to know, and I think it's the influence of the Language Workshop, because we hear many stories, and add them to our daily life to improve it.

Demeter: Yes, a lot. Sometimes I do something hastily, then I think: no!! I'm gonna do just like in the group of the Language Workshop. You have to think, make a decision. I've behaved better, I listen, I learned to listen, I'm not good at that, but I'm learning.

Athena:[...]When I got to the Language Workshop, I didn't speak, I was ashamed, and now I do speak!!

Artemis: Yes, because we feel our self-worth. Because there's experience exchange from the elderly to you, the young. It's a wisdom exchange, I think.

Zeus: Yes, it changed. Knowledge. My communication. I was shy, today I'm more outgoing. 


\begin{tabular}{|c|c|}
\hline Participants & Summary of the Language Workshop influence on their autonomy \\
\hline Hera & Confidence and freedom to write/ re-meaning of preconceptions \\
\hline Hestia & Confidenceto make decisions/strengthening of their own will \\
\hline Aphrodite & Acknowledgment of their own potentialities/ influence of the dialogical activities on their quality of life \\
\hline Demeter & $\begin{array}{l}\text { Acknowledgment of the need to make decisions in an elaborated and careful way/ listening started to be } \\
\text { considered }\end{array}$ \\
\hline Athena & More confidence to speak \\
\hline Artemis & Value of aging and the possibility to exchange experience with others \\
\hline Zeus & More autonomy to speak \\
\hline
\end{tabular}

Figure 1. Summary of the influence of dialogical activities on elderly's autonomy/decision-making, participants in the Language Workshop

\section{Second axis: influence of the Language Workshop on the coping with aging}

This axis tries to understand the influence that dialogical activities, produced during the meetings of the Language Workshop, may have on the way that the elderly conceive and cope with aging. Therefore, the following questions were elaborated: 1) "Has your participation in the Language Workshop influenced your way to cope with aging? 2) If so, what has changed on the way to cope with aging? If not, why?".

The elaborated responses to those questions were transcribed and presented, as follows.

Aphrodite: Yes, the contact with people..., the experience exchange makes you better, changes the way you see life.

Artemis: Yes, the interaction with other people improves your self-esteem, gives you more confidence to talk, I've changed my lifestyle, before, I got isolated at home, here, l've learned a lot.

Zeus: Yes, l've lost my shyness, changed my way to communicate, listen to people more, it was a wonderful experience, it's changed my way even toward my family, before, I got isolated at home.

Hestia: Yes, I've always been very active, but here, I've learned to look inside me, it improved my self-esteem... now that I'm old..

Hera: Yes, here you open your horizons, there's exchange between the people, you learn a lot, and teach, too, the fact of listening and being listened to, mainly for those who are hard of hearing, raises your self-esteem, it's changed my life.

Demeter: Yes, I was afraid of speaking before, got quiet, isolated, here, I was taken in, l've learned to respect and value myself, now, I give my opinion whenever I want to.

Athena: Yes and no, because I used to think that way, it just reassured what I thought, we need to accept and value ourselves, before, I spoke a lot, but didn't listen to others, now, l've learned to listen to and give my opinion, respecting the opinions of others.

\begin{tabular}{|c|c|}
\hline Participants & Summary of the Language Workshop influence on coping with aging \\
\hline Aphrodite & Experience exchange enabled well-being in aging. \\
\hline Artemis & The interaction with others fostered confidence and moved her away from isolation. \\
\hline Zeus & $\begin{array}{c}\text { The possibility to listen to others brought about changes in the family relationships and moved him away from a } \\
\text { position of isolation. }\end{array}$ \\
\hline Hestia & Despite perceiving herself as active, it promoted the self-reflection, enhancing the self-esteem in aging. \\
\hline Hera & The possibility to listen and be listened to enhanced her self-esteem. \\
\hline Demeter & Interaction experienced in the dialogical activities fostered her self-worth. \\
\hline Athena & The exercise of listening fostered the respect for the speaker, as well as for her own opinion. \\
\hline
\end{tabular}

Figure 2. Summary of the Language Workshop influence on coping with aging 


\section{DISCUSSION}

Regarding the participants' profile, prevalence of females can be observed. This phenomenon can be related to what has been called the feminization of aging, once women live longer than men almost all over the world ${ }^{2}$.

In a recent study, carried out by the Brazilian Institute of Geography and Statistics (Instituto Brasileiro de Geografia e Estatística) ${ }^{13}$, it was observed that women account for $55.8 \%$ of the elderly population in Brazil. That prevalence has been explained, among other factors, by the lower rate of smoking and alcohol abuse among them, less exposure to risks, for example, the fact that women live longer within household settings than men, which protects them from violent events ${ }^{14}$. In addition, they search for health services more often, being diagnosed earlier, thus, women have higher probabilities of cure from diseases ${ }^{15}$.

Considering schooling, there are significant differences in participants' educational levels: an elderly woman is literate, but did not attend school; one has incomplete middle school, and another has incomplete high school; a man and a woman graduated from high school; and two elderly women graduated from higher education. Lower levels of schooling can be explained by the conditions of the Brazilian educational system in the 1940s and 1950s, favorable to residents in urban centers. In that time, Brazil had an agricultural economy, with a significant number of children living in rural areas. Therefore, those children grew up and aged with lower levels of schooling ${ }^{16}$.

Moreover, illiterate population is fundamentally observed among aged people in the biggest country of South America, mainly among females. That is explained because women had less access to schooling until the mid-twentieth century, raised to be wives and mothers, responsible for their household duties and families ${ }^{16}$. As for their interaction, most researched subjects live with their family; only two aged women live alone. Anyway, it should be pointed out that the family relation is an important interactional and learning setting, which can promote affective relationships between the elderly and their family ${ }^{17}$.

Regarding the first axis, which addresses the influence of the Language Workshop on the elders' autonomy and decision-making, they reported in their speeches that after their participation in the Workshop, they feel more confident, freer to write, to make decisions, speak and listen to others. Athena and Zeus's accounts, for example, unveil that they felt shy and insecure before attending the Language Workshop.

Those accounts reassure the relevance of dialogical group activities to the interaction, by means of oral and written language. In addition, oral production activities, as the ones developed by the Language Workshop, are able to promote the autonomy among elderly subjects, providing them with new discursive situations, which value their opinions and experiences, expanding their possibilities of social participation. At this point, it should be highlighted that the National Health Policy to the Elderly ${ }^{6}$ states that autonomy reflects subjects' actions along their lives, and should be reassured in old age, so that elders actively participate in activities oriented to them in the community that they live in.

The participants in this study also reported that the dialogical activities developed in the Workshop strengthened their opinions, leading them to acknowledge their potentialities, as well as the influence that their life stories have over others. Hestia and Aphrodite's speeches point that, by participating in the activities mediated by interactional practices, they perceived the strength of their will, and the improvement of their quality of life. Their accounts show that they started to have more beneficial awareness of their own aging, by means of the relation established with the other participants, getting rid of prejudices and fostering more dignifying, autonomous and healthier aging.

The data found in this study are in agreement with a qualitative study held in Cajazeiras, Northeastern Brazil, which evidences that interactional activities enable the enhancement of personal confidence and quality of life, enabling greater social participation in the old age ${ }^{18}$. Similarly, another research held in Southern Brazil, points that elderly speakers, participants in dialogical practices, refer to perceive more clearly the need to change experiences, speak, listen to, defend their point of view and confront opinions, expanding their knowledge and demistifying their established and stigmatized positions on aging ${ }^{19}$.

The second axis refers to the influence, or not, that dialogical activities have on the way that the elderly cope with aging. From the enunciations produced by the participants, it is possible to understand it affirmatively, that is, the elderly perceive such influences as positive on aging, enabling experience exchange, possibilities to listen and be listened to, self-worth, respect for the other, and higher social participation, which, in turn, reduces isolation. Such aspects are in conformity with another study held among older subjects, whose 
results pointed that significant oral, reading and writing activities enabled the elderly more confidence and freedom to speak, read and write, reporting higher confidence, self-esteem and self-respect ${ }^{8}$.

Study on the influence of group activities over aging unveils that it is by means of group participation that older subjects have the possibility to build new ties and new ways to share their learning and life story with other subjects $^{20}$. Aphrodite, Zeus and Hera's accounts also reveal that. For them, experience exchange, enabled by the dialogical activities, changed the way that they perceive their own lives, improving their possibilities to relate to others.

Research on group interactions reports that group involvement is beneficial to the elderly participants, once it significantly contributes to the re-meaning of their personal history, overcoming their daily problems, development of healthy attitudes, rescuing the sense of well-being, belonging and helpfulness to others ${ }^{21}$. Artemis and Zeus's accounts clearly point that, before participating in the Language Workshop, they were isolated at home, with low self-esteem. Their speeches evidence that the dialogical group activity fostered changes, including in their family relationships, unfolding the importance of the elderly participation in interpersonal activities, able to promote greater social participation and experience exchange.

\section{FINAL CONSIDERATIONS}

The current research evidences that dialogical activities produced significant effects on the promotion of autonomy among elderly subjects, participants in a Language Workshop. Such experiences fostered more confidence, freedom to speak, strengthening of their will, in addition to greater social participation and confidence in decision-making. Thus, activities with and by means of the language, may play a fundamental role to apply the National Health Policy to the Elderly, since it brings about benefits related to the enhancement of the socio-verbal interaction, higher possibility to cope with aging, increase in the self-esteem and self-worth.

It should be considered that the results in this study do not allow generalizations, since they reflect discursive productions carried out by people from a certain community, who agreed to participate in meaningful activities with the language and with others for a specific period of time. However, this study may be useful as a reference for professionals that care for elderly individuals, so that they can consider the elderly's discursive productions, promoting their autonomy and decision-making, which they should exercise throughout their social and personal lives, according to the Public Policies oriented to that share of the population. Finally, the evidences in this study suggest the need to carry out research on the addressed theme, due to the scarcity of national and international studies approaching the role of dialogical relations in the process of active aging.

\section{REFERENCES}

1. Willig $\mathrm{MH}$, Lenardt $\mathrm{MH}$, Caldas $\mathrm{CP}$. A longevidade segundo histórias de vida de idosos longevos. Rev Bras Enferm. 2015;68(4):697-704.

2. World Health Organization. "Ageing well" must be a global priority. Geneva: WHO Press; 2014.

3. Dias EF. O envelhecimento populacional e o direito à saúde da pessoa idosa. Rev. Jurídica Direito, Sociedade e Justiça. 2013;1(1). Edição de Lançamento. Disponível. http://www. periodicosonline.uems.br.

4. Comissão Econômica para a América Latina e o Caribe (CEPAL). Boletín Envejecimiento y Desarrollo no13. Santiago de Chile: Cepal; 2016.

5. Brasil. Lei Federal ํㅜㄴ.741, de 01 de outubro de 2003. Estatuto do idoso. Brasília, 2003.

6. Brasil. Lei Federal $n-2.528$, de 19 de outubro de 2006. Política Nacional de Saúde da Pessoa Idosa. Brasília, 2006.

7. Wernet M, Mello DF, Ayres JRCM. Reconhecimento em Axel Honneth: contribuições à pesquisa em saúde. Texto Contexto Enferm. 2017;26(4):1-8.

8. Massi G, Wosiacki FT, Guarinello AC, Lacerda ABM, Carvalho TP, Wanderbrooke AC et al. Active aging: an intervention-research report. Rev. CEFAC. 2018;20(1):5-12.

9. Bakhtin M. Metodologia das Ciências Humanas. In: M. Bakhtin (ed). Estética da criação verbal. São Paulo: Martins Fontes; 2003. p. 393-410.

10. Sobral A, Giacomelli K. Observações didáticas sobre a análise dialógica do discurso - ADD. Domínios de Lingu@gem. 2016;10(3):1076-94.

11. Veneu A, Ferraz G, Rezende F. Análise de Discursos no Ensino de Ciências: considerações teóricas, implicações epistemológicas e metodológicas. Revista Ensaio. 2015;17(1):126-49.

12. Alvarez D, França MB, Figueiredo M. Exercício analítico sobre o método: aspectos linguageiros na atividade dialógica com trabalhadores de exploração e produção no setor petrolífero. Laboreal. 2015;11(1):39-52. 
13. Instituto Brasileiro de Geografia e Estatística. Síntese de indicadores sociais: uma análise das condições de vida da população brasileira: 2016. Rio de Janeiro: IBGE.

14. Nogueira IRR, Alcântara AO. Envelhecimento do homem: de qual velhice estamos falando? Revista Kairós-Gerontologia. 2014;17(1):263-82.

15. Ribeiro CRF, Guedes MBS, Figueiredo Júnior JM, Gomesda Silva PN. Resiliência de idosos institucionalizados participantes de um programa com jogos. Rev Bras Ativ Fis e Saúde. 2014;19(4):465-74.

16. Lisboa CR, Chianca TCM. Perfil epidemiológico, clínico e de independência funcional de uma população idosa institucionalizada. Rev Bras Enferm. 2012;65(3):482-7.

17. Cardoso LKB, Sampaio TSO, Vilela ABA. Cuidados fornecidos por familiares relacionados à convivência com o idoso. Revista KairósGerontologia. 2017;20(1):353-67.

18. Andrade AN, Oliveira MM, Duarte MM, Queiroga RM, Fonseca FLA, Lacerda SNB et al. Percepção de idosos sobre grupo de convivência: estudo na cidade de Cajazeiras-PB. Rev Bras Geriatr Gerontol. 2014;17(1):39-48.

19. Ferreira CK, Massi G, Guarinello AC, Mendes J. Inter generation language meetings: young and elderly people points of view. Distúrb. Comun. 2015;27(2):253-63.

20. Souza FPP, Massi GAA, Ribas A. Escolarização e seus efeitos no letramento de idosos brasileiros acima de 65 anos. Rev Bras Geriatr Gerontol.2014;17(3):589-600.

21. Missio MM, Vieira SV. Experiência em grupos de convivência de idosos: interfaces com a terapia ocupacional. Rev. Bras. Promoç. Saúde. 2019;32:7436. 